\title{
A Qualitative Study of the Perception of the People of Akyem Abuakwa Traditional Area on the Usefulness of the Chieftaincy Institution in Ghana
}

\author{
Yeyie Patrick $^{1 *}$, Ethel Gyimah ${ }^{1}$, Issaka Jacob ${ }^{2}$ \\ ${ }^{1}$ Kibi Presbyterian college of education, Kibi, Ghana \\ ${ }^{2}$ Jasikan College of education, Jasikan, Ghana \\ Email: patyeyie@gmail.com
}

\begin{abstract}
This paper seeks to create awareness on the perception of the people of Akyem Abuakwa about the usefulness of chieftaincy Institution in Ghana today. In pre-colonial Ghana, the chieftaincy institution was the main system of governance and adjudication of justice. It is the oldest form of government in Ghana. The institution equally in present times is ripped with a number of violent conflicts. With this development, some people are of the opinion that the institution has outlived its usefulness in contemporary Ghanaian society. There is the argument on the issue of chieftaincy institution and its usefulness in the Ghanaian society. Probing the situation, 200 indigenes from the Akyem Abuakwa state in the Eastern Region of Ghana were selected through quota and purposive sampling techniques in a cross-sectional study. The article found that few people in the traditional area believed that the institution is a potential source of conflict and violence while the majority of the people believed the institution is a blessing to the society because it brings about peace, stability and development in Ghana.
\end{abstract}

Keywords: chiefs, usefulness, outlived, Chieftaincy institution, Akyem Abuakwa

\section{Introduction}

The chieftaincy institution is the traditional authority in Africa. It is practised in Ghana and other African Countries. Chieftaincy as a social institution is practised by all of the ethnic groups in Ghana. In any traditional area, the traditional authority is usually referred to as a Council. The Council comprises of the paramount chief, divisional chiefs, subchiefs, elders, clan heads and the family heads. In Ghana the Traditional Authorities are very important institution in the development of the nation. Even though many are of the view that chieftaincy will lose its significance with the passage of time, the institution is still relevant.

According to history, at a point in time people began to nominate or elect their leaders. They select somebody who can speak and lead them. It was later adopted by the society and various changes made to allow for the selection of quality leaders. Today, the institution is one of the means by which African culture is showcased to the rest of the world. The powers of chiefs usually comes from the customs and traditions. A chief is a person who is elected or selected in accordance with customs and traditions and has been recognized by the government to rule people within a particular $\operatorname{area}^{[1]}$.

The Purpose of the paper is to assess the perception of the people of Akyem Abuakwa Traditional Area on the usefulness of the chieftaincy Institution in the development of Ghana.

In modern times, whatever role a chief or traditional ruler is allowed to play in the governance of his state depends very much on the attitude of that state to the institution of chieftaincy. In some states, the institution of chieftaincy has been subjected to some harsh and disturbing condition in other constituted states ${ }^{[2]}$. Before Ghana was colonized, the various indigenous states had well organized systems of governance constituted by chiefs and their council of Elders. The institution was part of the colonial administration during the rule of the Gold Coast. This recognition comes from the role chieftaincy played during the Colonial rule of Ghana's political history ${ }^{[3]}$. The institution deals directly with the local people and therefore impacts positively in terms of development in their area. The institution has and is still one of the significant institutions in the Ghanaian society over the years. Hence 1992 Ghanaian constitution recognizes the co-existence and

Copyright (C2020 Yeyie Patrick, et al.

DOI: https://doi.org/10.37256/ser.122020441

This is an open-access article distributed under a CC BY license

(Creative Commons Attribution 4.0 International License)

https://creativecommons.org/licenses/by/4.0/ 
important role played by the institution and grants the National and Regional a significant administrational function in the country ${ }^{[4]}$. A good traditional ruler focuses on the development that will transform his people positively. Chieftaincy institution supposes to help shape the future of kingdom and states by taken into consideration the differences of the people in the traditional area and bringing them together through fostering of unity for economic and social development. The institution should lead in the advocacy for patriotism among its members and to have a common appreciation of their history and heritage.

The institution is the custodian of the Ghanaian culture and ensures that all traditional activities and customs such as festivals are planned and performed. It is therefore through the institution that the people communicate with their gods and ancestors.

Chieftaincy is the custodian of traditional lands and stools. It holds these lands in trust for the living and the dead members of their communities. It is this custodianship that does not allow chiefs to use the lands for their personal gain, but to release them for projects that will benefit the people. The Chieftaincy institution is supposed to act as arbitrators in the community. The institution is supposed to settle all disputes arising out of misunderstanding among their people. They should bring disputing parties together and reconcile them to live peacefully in the community. This is to ensure peace and stability in the community, so that, people can live in a peaceful environment. In fact, the importance of chieftaincy institution cannot be overemphasized ${ }^{[5]}$.

\section{Review of related literature}

The literature was reviewed under two broad headings. It was reviewed on the two schools of thought who believed that the chieftaincy institution is no longer useful in the society and those who believed that the institution is still relevant to the society.

\subsection{School of thought that thinks that Chieftaincy Institution is still useful to the Ghanaian society}

According to Bombande ${ }^{[6]}$, The chieftaincy institution is one of the most influential Ghanaian institutions that brings collective, group and individual worldviews about culture and the Ghanaian traditional heritage. He therefore mentioned that any government that would undermine its credibility should be resisted by the society. Although not openly articulated inter-group competition in the modern democratic state is often along the lines of Chiefs. Bombande reiterates the significant role played by the institution when it comes to unity, preservation and transmission of the culture of the people. To him, the institution is still relevant and therefore political leaders should not undermine it.

In present Ghana, the political institution, the chieftaincy institution and indigenous political arrangement by which leaders with good moral standings are selected and installed in line with the provisions of their local customs and laws, makes the institution very powerful ${ }^{[7]}$. Formal political institutions such as the Police, the Court, Parliament and Electoral Commission, among others, work hand-in-hand in shaping the individual's life while the individuals equally have a responsibility to both systems ${ }^{[8]}$. Brobbey also emphasizes the important role played by the institution. A collaborative effort by chiefs and the governmental institutions helps in shaping the life of the individual while the individuals also remain responsible to the institutions. Thus, both traditional authorities and formal modern political institutions of democracy affect in various degrees, the internal (violent) conflicts in Ghanaian communities. Busia ${ }^{[9]}$ and Isaac ${ }^{[10]}$ have expressed that, traditionally, governance in pre-colonial Ghana was based mainly on the chieftaincy institution. The chiefs carried out their responsibilities with the help from their Council of Elders from the local to the state level ${ }^{[11]}$.

As noted by Isaac ${ }^{[10]}$, although these types of institutions were not synonymous to modern institutions in terms of responsibilities, they nonetheless created a similar level of unity and cohesion in their various communities as were found in Western countries at the time. The unity, peace and security of kingdoms, chieftains, and communities were largely dependent on the good leadership and protection of their kings, chiefs, sub-chiefs and community/family leaders that constituted the hierarchy of the chieftaincy institution. As Brobbey ${ }^{[8]}$ and Acquah ${ }^{[11]}$ noted, traditional governance evolved around the chieftaincy institution and the associated conflicts were resolved through customary arbitration with the chief assisted by his elders constituted as customary arbitrators from the local to the state level. The above clearly shows that, it is an undeniable fact that the institution is still important to the society in Ghana. The institution is the preserver and the transmitter of cultural heritage and agent of development, therefore must be maintained.

The significant roles played by institution in Ghana have been summarized by the Asantehene, Otumfuo Osei Tutu II as cited by Ayee ${ }^{[12]}$ :

He said "Their predecessors engaged in inter-tribal wars, fighting for conquest over territories and people. Today, 
the war should no more be against fellow humans but against dehumanization, poverty, marginalization, ignorance and disease." To him the institution must be used to bring improvement in the lives of the people through proper lands administration, community investments and codification of customs and traditions. According to him these would make it impossible for people who are not royals to get enstooled and creating situations for litigation. Thus the institution should pursue improvement for its members and the society as a whole. According to Otumfuo the unique nature of the institution makes it difficult for imposters to be enstooled.

Gyekye and Kendie \& Guri state that the African culture values, consensus building and social solidarity makes the institution very important. Apparently, during the pre-colonial times the institution was the mechanism for maintaining social order and stability ${ }^{[13]}$. To Gyekye et $\mathrm{al}^{[13]}$, the instituton was the source of unity and stability before colonization. Chiefs were able to maintain peace and other within their kingdoms and States.

Through the administrative practice of the public land sector agencies in Ghana, chiefs are usually required to give approval to land transactions within their area of jurisdiction. Thus, while clan and family heads may have some powers to allocate land, chiefs are to approve the transaction before it can be registered. The above shows that, they are the custodian of traditional lands in their area.

According to Benjamin and Emmanuel ${ }^{[14]}$, land ownership in Ghana vary from place to place but on most occasions are controlled by customary laws. To Benjamin \& Emmanuel, the institution is so important that they have the power to regulate land acquisition. They do that through their customary laws. They went ahead to say the chiefs adjudicate over land litigations within their area for a customary token fee. Chiefs have in recent times, been engaged in providing development through the setting up of education funds (e.g. the Otumfuo Educational Fund in Kumasi) and educating the people on the dangers of environmental degradation. According to Benjamin, and Emmanuel ${ }^{[14]}$, over $80 \%$ of land is under the control of chiefs. Chiefs, therefore, have a strong influence on agricultural productivity. This is because, as explained above, the institution must grant or approve for the sale or lease of a particular land before it can be used for agricultural purposes. The regulation of land and maintenance of peace and stability among their members, makes the institution very significant in the country.

\subsection{School of thought that thinks chieftaincy has outlived its usefulness in Ghana}

Despite the fact that the institution has some level of relevance in the Ghanaian society, its greatest challenge has always been conflicts, especially in the Northern part of the country. This has not only undermined the Institution but has also become a major security threat in the entire nation ${ }^{[19]}$.

According to the Minister of Chieftaincy and Religious Affairs, Kofi Dzamesi, there are about 356 chieftaincy disputes across Ghana. He said most of these disputes are caused by lack of well laid down succession plans. Succession to the throne according to the minister is based on un-codified customs and practices. These disputes have often resulted in bloody conflicts such as the Dagbon crisis, the Bimbilla chieftaincy crisis, Bawku Chieftaincy conflict, Ga Mantse succession dispute and Anlo chieftaincy conflict the minister stated.

Another major cause of chieftaincy conflict is the control of resources by Chiefs. In Northern Ghana for example Chiefs do not only command considerable respect amongst their subjects, they also have access to considerable resources including the labour of their subjects, land, livestock, minerals, water and trees of economic value ${ }^{[1,15]}$.

Worse of this problem is equally the fact that becoming a chief is not merely a contest between individual members of the royal group, but it also involves families, lineages and clans as well as their supporters ${ }^{[10]}$.

Besides being violent and continuous, a few chieftaincy conflicts in the north have also been alleged to be supported by the ruling government and the main opposition parties. Even though the Ghanaian Constitution does not allow chiefs to take part in partisan politics, some of the members of the institution are alleged to be declaring their support for some of the parties. In most cases individuals and feuding factions contesting for a throne align themselves to political parties. The Bimbilla and Dagbon Chieftaincy crises are examples.

A major development, however, as pointed out by $\operatorname{Hagan}^{[16]}$ is the numerous conflicts associated with the chieftaincy institution. In the view of Kendie and Bukari ${ }^{[13]}$, Ghana has often been described internationally as one of the most stable, democratic and peaceful countries in Africa. However, this image as a beacon of peace in Africa is marred by the many internal chieftaincy conflicts that have negative implications for local level development in these conflict areas. Shades of chieftaincy conflicts are witnessed across the ten regions. Notable among the conflicts recorded in recent times include the Ga Mantse succession dispute, Anlo conflict, Tuobodom chieftaincy conflict, Bimbilla chieftaincy affairs and the Yendi chieftaincy succession conflict ${ }^{[1,9,13]}$. The endemic nature of chieftaincy conflicts in Ghana and their implications for socioeconomic development and political stability has even made the institution to lose credibility in the society.

In spite of the significant role played by the chieftaincy institution in the lives of Ghanaians, Sutton, Abotchie and 
Awedoba ${ }^{[20-21]}$ and Prah and Yeboah ${ }^{[5]}$, have noted that the institution is full of conflicts. According to Prah and Yeboah ${ }^{[5]}$, these conflicts have been in the system for a long time and are widespread over the traditional areas. Chieftaincy institution is therefore perceived by some Ghanaians to have outlived its usefulness. While some of these conflicts have been peacefully resolved through both customary and legal arbitration, others have become protracted and destructive.

Notwithstanding the changing political landscape in the country, the institution is still forced to recon with. OwusuMensah $^{[18]}$ asserted that the chieftaincy institution has transcended the pre-colonial, colonial and post-colonial eras as well as three regime types: one-party, military and multi-party which demonstrates its resilience. Further, it remains the traditional and economic authority in most communities in Ghana. In opinion of Adjaye and Misawa ${ }^{[19]}$, chiefs are the channel and conduits for local development programs. As noted by Hagan ${ }^{[16]}$, several years after independence, chiefs have had the pleasure of witnessing the change of many radical leaders out of power and have also gained a reputation as spokespersons for rural dwellers and as stakeholders in state-building. Chiefs are increasingly becoming points for the evocations of local and ethnic pride. They are an epitome of pride in history and pride in hometown. They are not only the repositories of local history and spirituality, but upholders of local values. Thus, they saw the institution as conservatives who does not support modernization.

Despite the numerous importance of the tradition institution, the nation has had its share of violence clashes emanating from chieftaincy disputes. Reading Ghanaian newspapers, listening to radio or watching TV, one cannot help but feel that there are succession crises in the various institutions of the country. Most chiefs in Ghana ascend their thrones only to amass wealth and sell stool lands. They sell the same piece of land to different people creating confusion, riots, and violence among the people. Chiefs who are supposed to unite the people and ensure their safety hide behind land guards to drive away people from their land, cause damage to their properties and even cause injury to others.

There have been series of chieftaincy disputes in Ghana which have resulted in serious ethnic and tribal conflicts where many people have lost their life. A typical example was the chieftaincy issues where the late Ya-Na Yakubi Andani was assassinated and several people lost their lives in the Yendi traditional area in the Northern region. This brought about insecurity, chaos and tension among the people. Following the recent outbreak of chieftaincy crisis in most parts of the country, various analysts have attempted to reasons to such crises. These crises have raised tension in such communities. Some of the conflicts recorded in recent times as cited by Prah and Yeboah ${ }^{[5]}$ included the Dagbon crisis, the Ga Mantse succession dispute in 2007, Princess and Aketeyi towns trouble in 2007, the re-eruption of Tuobodom chieftaincy in 2010 the recent Bawku chieftaincy conflict, Wasipe chieftaincy succession in 1994 at Daboya, the Waala chieftaincy dispute in the early 2000 and the Kape chieftaincy crisis of the Bole traditional area in 2007. Nana Kwaku Dwumah Ankoana II (Omanhene of Seikwa) was shot dead in his chest. People from the royal family kill themselves in the name of chieftaincy. In recent times chiefs who are to be accorded respect engage themselves in sexual harassment of women. They go after married women and harm their respective husbands. In the area of justice, chiefs who are supposed to serve as arbitrators and administer fairness and justice in dealing with issues, collect bribes and blindly judge cases in favor of the rich and affluent at the expense of the poor. The rich in the society contest the position with the poorer royals who refuse to succumb to throne.

Kwesi Pratt mentioned that the institution is of no importance. In an interview on Metro TV on "Good Morning Ghana" he suggested that the state should not support the institution because of the numerous conflicts. He said, "The discrimination against blind people and other conflicts retards development in the country. He argued that there is no difference between the systems of Monarchy in other parts of the world and the chieftaincy in Ghana. He said it is the same system of chieftaincy which imposes a monarchy on Belgium and the same system in Europe, Latin America or Asia.

According to Aikins ${ }^{[19]}$, other people are growing beyond this old undemocratic system and moving onto higher forms. He supported his argument by adding that recently, a high-profile personality of Ghana's growing democracy and a former Deputy Speaker of Parliament stated that the institution of chieftaincy is undemocratic and full of anarchy and should therefore be abolished.

\section{Methods}

The study was conducted by analyzing and examining the important data from primary and secondary sources. The data collected from the primary source was from interviews while those from secondary sources was from published articles. A sample size of 200 was used through the convenience sampling method, because it does not consume time compared to other sampling techniques. five (5) other important respondents were selected through a purposive sampling technique in a cross-sectional study.

The respondents were interviewed in their various towns in Akyem Abuakwa Traditional Area. The respondents 
include some chiefs, farmers, petty traders, some religious leaders, teachers and individuals in the Area. The sampling method was made in such a way that there will be fair representation of the entire population with regard to towns and villages in the area.

\section{Findings}

Interviews with respondents in the Akyem Abuakwa Traditional Area revealed that only few respondents agreed with the saying that the Institution has outlived its usefulness in the Ghanaian society.

Anku, a farmer at Akyem Odumasi indicated;

The institution has brought a lot of conflict to the society. I recall a clash between two chieftaincy gates at Akyem Apedwa, a community close to Odumasi which resulted in the loss of two lives and the destruction of property. I therefore suggested the abolishing of the institution. (Field interview, November, 2019)

Okoe, a woman at Akyem Asafo also said:

The institution has brought a lot of land disputes to the society. I know some of the chiefs who are involved in double sales of land to buyers. This resulst in the employment of land guards who couse a lot of trouble in this area. (Field interview, November, 2019)

Adama, a cocoa farmer at Akyem Ahweniase indicated that:

To me chiefs are the cause of the illegal mining in this area. They normally sells out the lands to the artisanal miners popularly called "galamsey". This causes a lot of distractions to the water bodies in this area, therefore the institution should not be encouraged in the Ghanaian society. (Field interview, November, 2019)

The above is in line with Kwesi Pratt's suggestion that the institution should be abolished.

Out, a retired headteacher of Nyinasin M/A JHS asserted that;

The source of the numerous chieftaincy conflicts in the area is the 'enstoolment' and 'Destoolment' of chiefs. He said this makes this makes the institution less important in the society. He further argued that 'enstoolment' and 'destoolment' of chiefs have always put one of the traditional area against the other and this has made relationship between Traditional councils very bad.

The assertion above undoubtedly could negatively affect the development of the areas.

Jumbo an Assemblyman also said;

The influential role of some chiefs in the siting of headquarters of some Districts and Municipal Councils have led to major disputes in the area. Such disputes, arose when people were divided because government had acted contrary to their expectations; that the headquarters of a particular district or municipal council has not been established in their area Example is the siting of the District Capital of Abuakwa North at Akyem Kukurantumi instead of Akyem Tafo.

It could be argued that where these disputes have arisen, government's revenue is negatively affected.

Notwithstanding, most of the respondents think that the institution is still an important function in the society. The functions of the institution mentioned by them includes religious and cultural among others.

Kofi Pii, a teacher at Akyem Kukurantumi M/A JHS said;

I think chiefs by virtue of their position performs many roles including decision making and serves as a leader in his community. The chiesf attends important meetings and ceremonies on behalf of his subjects. He performs intermediary role by relating to others outside his society, he acts the role of an information giver by transmitting information to his subjects. (Field interview, November, 2019)

Ayewaa, a petty trader at Akyem Nsutam said;

I know for sure that chiefs are our representatives when it comes to issues concerning my locality and the outside world. Our paramount chief always represents us at occasions outside the area. (Field interview, November, 2019)

Guite, a carpenter at Akyem Akropong said;

The chief initiates developmental projects in our communities. Aside that He settles disputes between various feuding factions among family member and the members of our communities. This brings peace and unity in the communities. (Field interview, November, 2019)

The above is in line with what Boafo-Arthur, Lutz and Linder who noted that traditional courts are popular, easy to access and cheap ${ }^{[17]}$.

Yao, an opinion leader at Akyem Asafo said;

I think the ruling of localities in the country will be easy if it were to be rules by only the government. The chiefs have to help and support the government to be successful in ruling the country. I must state that without the chiefs, it will be difficult for the government to rule the whole country. (Field interview, November, 2019) 
Bonsu, a farmer at Akyem Wirenkyiren said;

The chiefs and the council of elders decide on the type of development projectsto be undertaken in our area. After that, a collective decision is made at the chief's palace to plan to execute the projects. As a result, everyone agrees to support during communal labour. (Field interview, November, 2019)

A sub-chief at Kyebi Ahenfie mentioned that:

There was a time when World Bank's decided to help the traditional authorities' with some projects in Ghana, under this project they provided some grant directly to the Akyem Abuakwa Traditional Council. The project actually helped to improve on the health and education of the people. This shows that the chief traditionally plays an important role in the development of his people.

Another sub-chief at Akyem Apapam said;

I know the chief is the one who takes care of the stool lands for the people. He brings changes in terms of development of the community and so he is very important. (Field interview, November, 2019)

Yaa Dua, at Akyem Potroase said;

Our chiefs, settles disputes that arises between the members in his communities. They also purify the god of our land anytime we offend them. So they are the link between the living and the dead. (Field interview, November, 2019)

Odi, a cassava farmer at Akyem Adonkwanta said;

One important role of our chiefs is the negotiating and reaching agreements with other communities in cooperation and exchange of ideas to bring development to the people. (Field interview November, 2019)

The above shows that the institution plays very important role in the society to bring about development.

Yayo, a petty trader at Akyem Maase said;

I know from the beginning that, chiefs in this area have always involved their subjects in decision making. As it always said 'two wise heads are better than one' he invites views from the members on issues concerning our community. (Field interview, November, 2019)

Daworo, a traditional prist at Akyem Bonsu said;

Our chief also serves as the link between the people and the government. He does that by giving information about the policies of the government and also inform the government on the various challenges facing his people. (Field interview, November, 2019)

Ofori Atta, a carpenter at KIbi indicated;

That majority of Ghanaians, especially those who live in rural areas accord more respect to traditional authorities than government's representatives in the area. I know in times of natural disasters, the chief's palace is the first to be informed before the other stake holders. The chief becomes a mobilizing force to gather people and other resources to address any problem caused by the disaster. (Field interview, November, 2019)

The above comments from the respondents clearly shows that the people of Abuakwa traditional areas are of the view that, though the chieftaincy institution has some challenges, the institution is very useful to the society.

There might be other challenges encountered in the effort of stakeholders in the integrating chieftain system with the modern society to bring about development to the people but critical among them are the numerous disputes as discovered by this paper. The institution was a powerful one when it comes to development of the local area, but due to the various challenges, the institution might be gradually loosing that power to the modern government. This might not help in the development of the local society and the world. The institution exist and functions not only in Ghana but across Africa and the world. It is an undeniable fact that the institution has played a significant role among the society in Ghana, Africa and the world. Therefore such an important institution should not be allowed to be destroyed by disputes and other challenges. The Authors believe that those who have stake in the institution would make every effort necessary to minimize if not eradicate the challenges among the institution to bring about development to the society, Africa and the world.

\section{Conclusion}

It is an undeniable fact that despite the numerous chieftaincy disputes and conflicts, the people of Akyem Abuakwa still believe that the chieftaincy institution is very important and must be supported by government and stakeholders to bring about peace, stability and development to the communities. This tells the reasons for which the laws of Ghana still make provisions for the institution. The views above supports the view that the institution is still relevant to the Ghanaian society. There are a few people who think that the chieftaincy institution has outlived its usefulness due to the numerous disputes. This perception, even though is true to some extent does not outweigh the positive impact of chiefs on their people. The local authority is seen as the symbol for unity and stability in the society. They are believed by their subjects 
to be able to organize material and human resources to bring about development to their people. In conclusion, it was found out that though some few people in the Akyem Abuakwa area thinks that the chieftaincy institution has outlived its usefulness, most of the people think that the institution is still relevant and it should be supported to bring about peace, stability and development to the people in the society.

\section{Recommendations}

In sum, the study finds that the chieftaincy institution has not outlived its usefulness in Ghana. Some of the informants recommended that some rules and regulations should be enacted to guide the selection and enstoolment or enskinment of chiefs to eliminated indiscipline among some chiefs.

Secondly, an amount of money should be paid from the District Assembly common fund to be paid to chiefs at the end of every month to help them make ends meet to avoid their involvement in illegalities.

Again a legislative instrument should be enacted in parliament spelling out clearly the dos and don'ts of chiefs and the punishment that should be meted out to recastrante chiefs. This would help reduce if not eradicate the impact those whose behavior brings the institution into disrepute.

To add to that, Chiefs should keep to the provision in the Constitution that prohibits them from taking part in partisan politics. This help maintain the respect and dignity for the members of the institution.

Furthermore, in every human endeavor, there is bound to be misunderstanding, and chieftaincy is not an exception. Those mandated by law to adjudicate matters concerning chieftaincy, should try to resolve such issues quickly devoid of partiality and favoritism to bring about peace and unity.

Finally, matters concerning chieftaincy should not be discussed on social media, it should be handled by institutions, organizations and individuals who have knowledge in the institution.

\section{Reference}

[1] Arhin, Brempong. Transformations in Traditional Rule in Ghana. 2001.

[2] Acquah Justice G. K. The Judicial Role of the Chiefs in Democratic Governance. Legon, Accra: Institute of African Studies, Sub-Saharan Publishers; 2006.

[3] Owusu-Mensah, I. Politics, Chieftaincy and Customary Law in Ghana; Kas International Reports of the KonradAdenauer-Stiftung. Konrad-Adenauer-Stiftung e.V. Berlin, Germany; 2013.

[4] Government of Ghana. The Constitution of the Republic of Ghana. Accra, Ghana: Asempa Publishers; 1992.

[5] Prah, M, Yeboah, A. Tuobodom Chieftaincy Conflict in Ghana: A Review and Analysis of Media Reports. The Journal of Pan African Studies. 2011; 4(3): 20-32.

[6] Bombande, E. Sources and Resolutions of Chieftaincy and Land Conflicts in Ghana. Accra: Center for International Peace Operations; 2011. p.24-38.

[7] Nweke, K. The Role of Traditional Institutions of Governance in Managing Social Conflicts in Nigeria's Oil-Rich Niger Delta Communities: Imperatives of Peace-Building Process in the Post-Amnesty Era. British Journal of Arts and Social Sciences. British Journal Publishing Inc; 2012; 5(2).

[8] Brobbey, S. A. The law of chieftaincy in Ghana. Accra: Advance Legal Publications (ALP); 2008. Brukum, N. J. K. Chieftaincy and Ethnic Conflicts in Northern Ghana, 1980-2002. In: Chieftaincy in Ghana. Culture, Governance and Development, Odotei, I. K., Awedoba, A. K. (eds.) Legon, Accra, Ghana: Sub-Saharan Publishers; 2006. p.429-445.

[9] Busia, K. A. The Position of the Chief in the Modern Political System of Ashanti. Accra: Assembly Publishing; 1968.

[10] Isaac, O. M. Politics, Chieftaincy and Customary Law in Ghana. Konrad Ardenuer Foundation (KAS) International Reports; 2013.

[11] Acquah, G. K. The Judicial role of the Chief in Democratic Governance. In: Chieftaincy in Ghana: Culture Governance and Development, Odotei, I. K., Awedoba, A. K. (eds.) Legon, Accra, Ghana: Sub-Saharan Publishers; 2006. p.65-79.

[12] Ayee, J. R. A. Traditional leadership and local governance in africa: The ghanaian experience: Paper presented at the Fourth National Annual Local Government Conference on the theme "Traditional Leadership and Local Governance in a Democratic South Africa: Quo Vadis" held from 30-31 July 2007 at the Southern Sun-Elangeni, Durban.

[13] Kendie, S. B., Bukari, K. N. Conflict and its effects on development in the Bawku Traditional Area. University of Cape Coast Journal of Arts and Social Sciences. 2012; 1(1): 1-9. Lederach, J. P. The Little Book of Conflict Transformation. USA: Good Books, Intercourse, PA; 2003. Nukunya, G. K. Tradition and Change in Ghana: An introduction to Sociology. 2nd ed. Accra: Ghana Universities Publishing; 2003.

[14] Benjamin, Emmanuel. Cieftaincy in Ghana, Governmence and Development Accra. Sub-Saharan Publishers; 2014. 
[15] Odotei, K. I., Awedoba, K. A. Chieftaincy in Ghana: Culture, Governance and Development; Accra, Ghana: SubSaharan Publishers; 2006. p.700.

[16] Hagan, G. P. Epilogue Chieftaincy in Ghana: Culture, Governance and Development. In: Chieftaincy in Ghana. Culture, Governance and Development, Odotei, I. K., Awedoba, A. K. (eds.) Legon, Accra, Ghana: SubSahara Publishers; 2006. p.663-673.

[17] Boafo-Arthur, K. Chieftaincy in Ghana: Challenges and Prospects in the 21st Century. In: Chieftaincy in Ghana. Culture, Governance and Development, Odotei, I. K., Awedoba, A. K. (eds.) Legon, Accra, Ghana: Sub-Saharan Publishers; 2006. p.145-168.

[18] Owusu-Mensah, I. Queen Mothers: The Unseen Hands in Chieftaincy Conflicts Among the Akan in Ghana: Myth or Reality? The Journal of Pan African Studies. 2015; 8(6): 1-16.

[19] Adjaye, J. K., Misawa, B. Chieftaincy at the Confluence of Tradition and Modernity: Transforming African rulership in Ghana and Nigeria. International Third World Studies Journal and Review XVII. 2006.

[20] Aikins. Modes of Succession in the Upper East Region of Ghana. In: Chieftaincy in Ghana. Culture, Governance and Development, Odotei, I. K., Awedoba, A. K. (eds.) Legon, Accra, Ghana: Sub-Saharan Publishers; 2006. p.409-427.

[21] Abotchie, C. Awedoba, A., Odotei, A. Perceptions on Chiefs. In: Chieftaincy in Ghana: Culture, Governance and Development, Odotei, I. K., Awedoba, A. K. (eds.) Legon, Accra, Ghana: Sub-Saharan Publishers; 2006. p.103-144.

[22] Awedoba, A. K., Odotei, I. Chieftaincy in Ghana. Culture, Governance and Development Accra. Sub-Saharan Publishers; 2006. 